\title{
Soft drink intake, television, video viewing and video game playing compared among normal weight and overweight preschool-aged children in rural West Virginia
}

Meredythe Barrick

West Virginia University

Follow this and additional works at: https://researchrepository.wvu.edu/etd

\section{Recommended Citation}

Barrick, Meredythe, "Soft drink intake, television, video viewing and video game playing compared among normal weight and overweight preschool-aged children in rural West Virginia" (2006). Graduate Theses, Dissertations, and Problem Reports. 2351.

https://researchrepository.wvu.edu/etd/2351

This Thesis is protected by copyright and/or related rights. It has been brought to you by the The Research Repository @ WVU with permission from the rights-holder(s). You are free to use this Thesis in any way that is permitted by the copyright and related rights legislation that applies to your use. For other uses you must obtain permission from the rights-holder(s) directly, unless additional rights are indicated by a Creative Commons license in the record and/ or on the work itself. This Thesis has been accepted for inclusion in WVU Graduate Theses, Dissertations, and Problem Reports collection by an authorized administrator of The Research Repository @ WVU. For more information, please contact researchrepository@mail.wvu.edu. 


\author{
Meredythe Barrick \\ Thesis submitted to the College of Agriculture, Forestry and Consumer Sciences \\ At \\ West Virginia University \\ in partial fulfillment of the requirements \\ for the degree of \\ Master of Science \\ in \\ Family and Consumer Sciences \\ Cindy Fitch, Ph.D., RD, Chair \\ Betty Forbes, M.A., RD, L.D. \\ Janet Tou, Ph.D.
}

Division of Family \& Consumer Sciences

Morgantown, West Virginia

2006 


\section{ABSTRACT \\ SOFT DRINK INTAKE, TELEVISION, VIDEO VIEWING AND VIDEO GAME PLAYING COMPARED AMONG NORMAL WEIGHT AND OVERWEIGHT PRESCHOOL-AGED CHILDREN IN RURAL WEST VIRGINIA}

\section{Meredythe Barrick}

Recently, there has been a rise in overweight in children. Overweight in children is associated with chronic diseases in childhood and adulthood. This study aimed to analyze factors that may influence weight of children. Specifically, average soft drink consumption, average hours of television/video viewing/ video game playing, and mothers' BMI were compared among overweight and normal weight preschool-aged children in rural West Virginia.

Children, mean age 52 months, residing in McDowell or Mercer counties in West Virginia. Parents or other caregivers completed 24-hour dietary recalls. They also provided average hours of TV/video viewed/video games played by children. Subjects consisted of overweight, $\mathrm{BMI} \geq 85^{\text {th }}$ percentile, and normal weight, $\mathrm{BMI}<85^{\text {th }}$ percentile, children.

A positive correlation between mother's BMI and child BMI was the only significant finding $(\mathrm{P}<0.001)$. These results indicate a need to perform more studies on factors related to overweight in these children. 


\section{ACKNOWLEDGEMENTS}

I would like to thank Dr. Cindy Fitch for her assistance and advice as my committee chair. She supported me from day one and has been patient through the whole process. She has been an excellent advisor throughout my college career.

I thank Betty Forbes for her encouraging words and her time as a committee member. She provided knowledge and patience.

I thank Dr. Janet Tou for her assistance and contribution of knowledge. I have only known her for a short time, but she has become a friend. She provided both constructive criticism and encouragement.

I would also like to thank my husband, Brent Barrick, my parents, Tim and Ginny Newlin, and my brother, Geoff Newlin for their support and encouragement throughout my life.

Last, I thank God for everything. 
Table of Contents

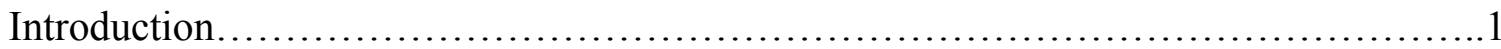

Review of Literature ..........................................................

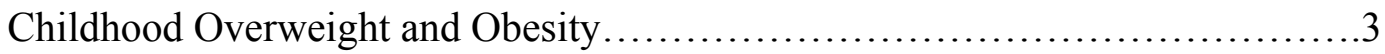

Relation of Parental Overweight and Obesity to Child Overweight..............5

Relation of Childhood Overweight to Cardiovascular Risk Factors...............6

Childhood Soft Drink Consumption...................................

High-Fructose Corn Syrup..........................................11

Television Viewing................................................. 12

Statement of the Problem................................................

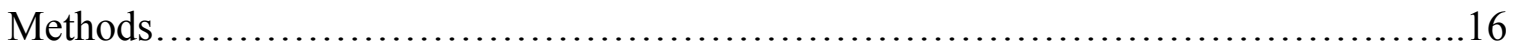

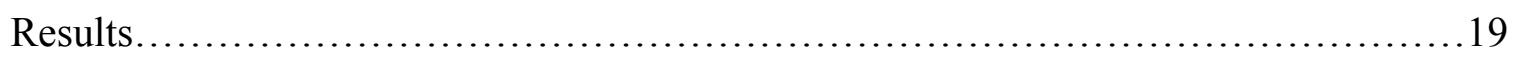

Discussion............................................................. 21

Conclusion............................................................... 24

References............................................................ 25

Appendices............................................................... 27

Appendix A....................................................... 28

Appendix B......................................................29

Appendix C....................................................... 30

Appendix D....................................................... 31

Appendix E....................................................... 32

Appendix F...................................................... 34

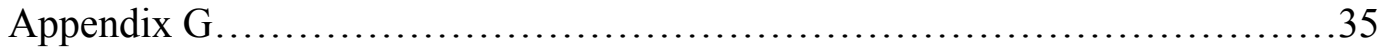




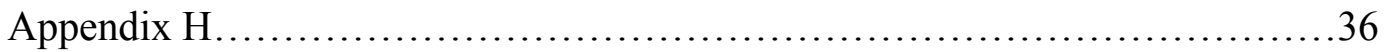

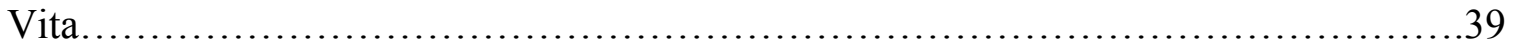




\section{List of Charts}

Page

Chart 1: Subjects soft drink consumption..................................... 


\section{Introduction}

Overweight and obesity in children (2-16 year-olds) is associated with various chronic disease risk factors in childhood as well as in adulthood (Freedman et al, 1999). If it is possible to prevent the progression of overweight and obesity in early childhood, it may be possible to decrease the prevalence of children and adults with cardiovascular disease, type 2 diabetes, cancers, or other chronic diseases. Type 2 diabetes was the fifth cause of death in the United States in 2002, although it is believed to be under-reported on most death certificates (American Diabetes Association, 2006). Type 2 diabetes is also associated with increased cardiovascular disease risk. Cardiovascular disease is the leading cause of death and disability in North America (Kavey et al, 2003). Therefore, decreasing the prevalence of chronic diseases can decrease mortality.

Many other health consequences can occur in early childhood due to overweight or obesity. Examples include sleep apnea and other respiratory problems as well as early onset of type 2 diabetes.

In order to make changes, it is necessary to analyze various lifestyle and environmental factors that are associated with childhood overweight and obesity. Factors believed to contribute to the rise in child overweight include increases in energy intake, specific nutrients intake such as fat and sugar, and physical inactivity, as well as genetics. Of these, energy intake, nutrient intake, and physical inactivity can be modified. Recently, there has been a concurrent rise in child and adolescent soft drink intake and child and adolescent overweight. Nielsen and Popkin (2004) showed that from 19772001 , soft drink consumption by 2 - to 18 -year-olds increased from $3.0 \%$ to $6.9 \%$ of total energy. One specific component of soft drinks that may contribute to overweight is high fructose corn syrup (HFCS). HFCS began to be used in 1966, when it replaced sucrose in 
many sweetened foods, such as soft drinks. There has been recent research that suggests HFCS may affect the body's metabolism and hunger suppressors (Elliott et al, 2002). From the third National Health and Nutrition Examination Survey (NHANES), Andersen et al (1998) found that many US children watch a great deal of television and are inadequately active. Both high amounts of television viewing and low amounts of vigorous activity were related to overweight and high fatness in children aged 8 through 16 years.

West Virginia is an ideal state to study factors related to overweight and obesity because of the high prevalence of adult obesity and it is a rural state. West Virginia ranks third in the United States for adult obesity. The prevalence of obesity has been increasing in West Virginia as well as the entire United States. See Figure 1 (Appendix A) for the prevalence of obesity in West Virginia.

In order to analyze the effect of childhood eating habits and lifestyle factors on weight, data were collected in McDowell and Mercer counties in West Virginia. Mercer county has a population of 62,070 with $19.7 \%$ of residents being below the federal poverty level. African-Americans make up 5.8\% of the population of Mercer county (West Virginia Demographics, 2004). McDowell county has a population of 24,726 with $37.7 \%$ of residents being below the federal poverty level. African-Americans make up $11.9 \%$ of the population of McDowell county. See figure 2 (Appendix B) for a map of West Virginia and the location of McDowell and Mercer counties. These two counties were selected because they are rural communities with strong Family Nutrition Programs. In addition, McDowell County has the state's highest prevalence of adult obesity (West Virginia Department of Health and Human Services, 2004). 
The factors analyzed in this study included daily intake of soft drinks, mother's body mass index (BMI) and daily hours of television watched or video games played. This study investigates the association between these variables and child weight group.

\section{Review of Literature}

\section{Childhood Overweight and Obesity}

A measurement called percentile of Body Mass Index (BMI) is used to identify overweight and obesity in children and adolescents. The Centers for Disease Control (CDC), the supplier of national growth charts and prevalence data, avoids using the word "obesity" for children and adolescents. Instead, they suggest two levels of overweight: 1) the $85^{\text {th }}$ percentile, an "at risk" level, and 2) the $95^{\text {th }}$ percentile, the more severe level. Ogden et al. (1997) examined the prevalence of overweight and obesity among preschool children (age 2-5) in the United States from 1971 through 1994. These researchers used three National Health and Nutrition Examination Surveys and the Hispanic Health and Nutrition Examination Survey (HHANES) to assess the prevalence of overweight and obesity in preschool children. NHANES is a nationally representative sample of the US. NHANES I was conducted from 1971 through 1974, NHANES II was conducted from 1976 through 1980, HHANES was conducted from 1982 through 1984, and NHANES III was conducted from 1988 through 1994. The definition of overweight was based on the National Center for Health Statistics (NCHS) weight-for-stature and weight-for-length curves. The prevalence of overweight in this research was defined as the percentage of children whose was above the $95^{\text {th }}$ percentile of the growth curve. Results from the NHANES showed the prevalence of overweight was higher among children 4 to 5 years of age $(7.9 \%)$ than among children 2 to 3 years old (3.4\%). The 
NHANES researchers also reported that the prevalence of overweight among girls was significantly $(\mathrm{P}<0.01)$ higher than among boys for all groups. Over $10 \%$ of 4 - and 5 year-old girls were overweight in 1988 through 1994; whereas, 5.8\% of 4- and 5-year-old girls were overweight in 1971 through 1974. These results suggest that strategies aimed to prevent overweight need to start in early childhood.

Ogden et al (2002) later conducted research using a follow-up NHANES from 1999-2000. The main findings were that the prevalence of overweight was $10.4 \%$ among 2- through 5-year olds compared to 7.2\% in 1988-1994 (NHANES III). Overweight was still defined as weight-for-stature or weight-for-length $\geq 95^{\text {th }}$ percentile. This concludes that overweight in children in the United States is continuing to increase.

Mei et al (1998) examined whether the prevalence of overweight in low-income US preschool children increased between 1983 and 1995. Low-income was defined as participation in the Special Supplemental Nutrition Program for Women, Infants, and Children (WIC). Data for this research were taken from the Pediatric Nutrition Surveillance System (PedNSS). PedNSS data comes from clinic service records of the WIC program. Data were collected from 18 US states including the District of Columbia. Weight-for-height percentiles calculated by using the NCHS/CDC age- and sex-specific growth reference were used to estimate the prevalence of overweight or obesity. Weightfor-height status above the $85^{\text {th }}$ percentile was considered overweight, while status above the 95th percentile was considered obese. The results of this research showed the prevalence of overweight based on the weight-for-height 85 th percentile cutoff point increased significantly $(\mathrm{P}<0.05)$ from $18.6 \%$ in 1983 to $21.6 \%$ in 1995 for children 0 to 59 months old from low-income households. Based on the 95th percentile cutoff point, 
the prevalence of obese children in low-income households increased significantly from $8.5 \%$ in 1983 to $10.2 \%$ in 1995 . In contrast to the above research, the Mei et al (1998) study showed a parallel increase in the prevalence of overweight for boys and girls; however, the prevalence of overweight for girls was significantly higher than for boys. This research emphasizes the fact that tactics to prevent overweight and obesity need to start at a young age because it can track into adulthood (Mei et al, 1998). While it is imperative that the prevalence of overweight and obesity in childhood be researched, it is also necessary to determine the potential factors responsible for childhood overweight and obesity during childhood.

\section{Relationship of Parental Overweight and Obesity to Child Overweight}

Whitaker et al. (1997) investigated the risk of obesity in children and adults and the relationship to obesity in one or both parents. Measurements of height and weight were obtained from clinical records of 854 subjects born at Group Health Cooperative of Puget Sound, Washington between 1965 and 1971. Parental medical records were also reviewed for height and weight measurements. Childhood obesity was defined as a BMI $\geq$ the $85^{\text {th }}$ percentile for age and sex. Adult obesity was defined as a mean BMI $\geq 27.8$ for men and $\geq 27.3$ for women.

Results showed that $16 \%$ of subjects were obese in young adulthood (21-29 years of age). At 1-2 years of age, $73(9 \%)$ subjects were obese. At 3-5 years of age, $86(11 \%)$ subjects were obese. Among the subjects obese in childhood, the chance of obesity in adulthood ranged from $8 \%$ for 1 - to 2 -year-olds without obese parents to $79 \%$ for 10 - to 14-year-olds with at least one obese parent. Parental obesity more than doubled the risk 
of adult obesity among both obese and non-obese children under 10 years of age

(Whitaker et al, 1997). Magarey et al (2003) found similar findings.

\section{Relation of Childhood Overweight to Cardiovascular Risk Factors}

Freedman et al. (1999) looked at data collected in the Bogalusa Heart Study. The Bogalusa Heart Study was conducted between 1973 and 1994, and studied cardiovascular disease (CVD) risk factors in early life. The sample these researchers analyzed consisted of 9,167 schoolchildren aged 5- to 17-years-old examined in the Bogalusa Heart Study. Girls made up $52 \%$ of the children. Measurements included height, weight, serum total cholesterol (TC) and triglycerides (TG), as well as low-density lipoprotein cholesterol (LDL-C) and high-density lipoprotein cholesterol (HDL-C). Systolic and diastolic blood pressures (SBP and DBP, respectively) were also measured. Overweight was defined as

a Quetelet index above the $95^{\text {th }}$ percentile of combined data from the Health Examination Surveys II and III and NHANES I, II, and III. Risk factors for CVD were defined as follows: High levels of TC were those above $200 \mathrm{mg} / \mathrm{dL}$ and LDL-C were those above $130 \mathrm{mg} / \mathrm{dL}$. A high TG level was greater than or equal to $130 \mathrm{mg} / \mathrm{dL}$. A HDL-C below $35 \mathrm{mg} / \mathrm{dL}$ was considered low. Subjects were considered to have elevated blood pressure levels based on the National High Blood Pressure Education Program.

Results showed that of the 9,167 schoolchildren, $10.8 \%$ were considered overweight. Overweight children were more likely to have increased CVD risk indicated by there likelihood to be 2.4 times more likely to have elevated TC levels, 2.4 times as likely to have elevated DBP, 4.5 times as likely to have elevated SBP, 3.0 times more likely to have high LDL-C, 7.1 times more likely to have high TG, and 3.4 times more likely to have low HDL-C than children at less than $85^{\text {th }}$ percentiles. Of the 813 children 
found to be overweight, $58 \%$ had one or more risk factors for CVD. This is substantially higher than the percentage of risk factors found in children who were within a normal weight range (Freedman et al, 1999). While unfavorable lipid profiles may be due to poor health practices, these could also be due to genetics. The relationship to genetics was not adequately studied.

Berenson (2005) performed a meta-analysis on the Bogalusa Heart Study to further examine the relationship between obesity and cardiovascular risk factors. From the $1970-80 \mathrm{~s}$, the average increase in body weight of children was $2.5 \mathrm{~kg}$. This increase in weight occurred without a significant increase in height.

This research further emphasizes the need for early prevention of overweight in children to help prevent future chronic diseases.

\section{Childhood Soft Drink Consumption}

One modifiable factor that could be related to the rising incidence of childhood obesity is the concurrent rise in consumption of soft drinks.

Nielsen and Popkin (2004) analyzed the changes in US beverage intake between 1977 and 2001. Data were collected from four nationally representative, independent surveys of the US population. Subjects were aged 2-years and older. The surveys used were the 1977-1978 Nationwide Food Consumption Survey (NFCS77) $(29,695$ participants), the 1989-1991 Continuing Survey of Food Intake by Individuals (CSFII89) (14,658 participants), the 1994-1996 CSFII (CSFII96) (19,027 participants), and the NHANES 99-01 (9,965 participants). Results from this research revealed that between 1977 and 2001, Americans increased the proportion of total energy obtained from soft drinks from $2.8 \%$ to $7.0 \%$. The proportion of total energy from fruit drinks increased 
from $1.1 \%$ to $2.2 \%$ and energy intake from milk decreased from $8.0 \%$ to $5.0 \%$ for all age groups. In the 2- to 18-year-old age group, soft drink consumption increased from $3.0 \%$ to $6.9 \%$ of total energy. However, the age groups were broad; hence, accurate data on different age groups are questionable. Therefore, it is important to examine smaller ranges of age groups and the consumption of sugar-sweetened beverages. In this study, we examined an age group of 2-6 year-olds.

The increasing prevalence of childhood overweight is not only in the US, but also in all developed countries. England is a country in which childhood overweight is becoming more prevalent. Northstone et al, (2002) examined the types of beverages consumed by 18-month-old children in England. The researchers used data from the Avon Longitudinal Study of Pregnancy and Childhood (ALSPC). Children studied were born between June and December 1992. When the children were 6-months old, mothers were asked to record what their child ate and drank over a 3 day period; however, only the beverage information from day 1 was used in this study. Socio-demographic information was also studied.

In all, mothers of 1,026 children completed dietary records. Results showed that $92.4 \%$ of children studied consumed cows' milk once a day. Most of these children drank whole milk, but $10 \%$ drank low-fat and $<1 \%$ drank skim milk. When sociodemographic variations were considered, mothers with the lowest education levels were significantly more likely to give their children tea or coffee and "fizzy drinks" (soft drinks).

A review performed by St-Onge et al. (2003), focused on the changes in childhood food consumption patterns. After reviewing a number of previously published 
research articles, the authors found that as the prevalence of overweight in children aged 6-11 years increased from 1971-1996, so did the consumption of soft drinks and fast foods. Since 1971, the rates of overweight in children have almost tripled. Between 1977 and 1996, the percentage of foods that children consumed away from home (restaurants and fast food outlets) increased by almost $300 \%$.

Harnack et al (1999) explored the nutritional consequences of soft drink consumption among US children and adolescents. Data collected were part of the 1994 Continuing Survey of Food Intakes by Individuals (CSFII). Two days of dietary recall data collected were used to derive information on food and nutrient intake. Dietary recalls for children aged 2 to 5 years were conducted with proxy interviews. The proxy was preferably the person most often responsible for preparing the meals. The 1994 CSFII collected data from a nationally representative sample of people of all ages in the US. This research analyzed data on children aged 2 to 18 years. Of approximately 6,973 subjects, 5,311 completed 2 days of dietary recalls. Of the 5,311 who completed 2 days of dietary recalls, 1,810 were children aged 1 to 18 years. Preschool aged children were 2 to 5 year olds. Multiple linear regression modeling was conducted to determine whether nutrient intake was related to soft drink consumption. Specific nutrients studied include calcium, riboflavin, vitamin A, phosphorus, folate, and vitamin C. These are nutrients found in fruit juices and milk, beverages that may be replaced by soft drinks in the diet.

A significant finding was at a $\mathrm{P}$ value $\leq 0.05$. Harnack et al reported that $49.5 \%$ of preschool age children were non-consumers of soft drinks (those consuming no soft drinks during the 2 days of dietary recall), while $38.9 \%$ of preschool age children 
consumed an average of 0.1 to $8.9 \mathrm{oz} / \mathrm{d}$. Logistic regression analyses indicated significant differences in the predicted odds of soft drink consumption by race for preschool-aged children and adolescents. Whites (odds ratio 2.03) were more likely than blacks (odds ratio 1.00) to consume soft drinks. No significant difference $(\mathrm{P}>0.05)$ in soft drink consumption by region of the country or poverty status was found. Especially interesting is that the percentage of energy from protein was lower among those children consuming the most soft drinks. Preschool-aged children consuming $\geq 9 \mathrm{oz} / \mathrm{d}$ of soft drinks had $13.1 \%$ of energy from protein while nonconsumers had $15.3 \%$ of energy from protein. The difference was significant $(\mathrm{P} \leq 0.05)$.

Skinner et al (2004) described the transitions and patterns in infants' and toddlers' beverage intakes. The Feeding Infants and Toddlers Study (FITS) provided the data. FITS was a nationwide cross-sectional study that obtained 24-hour dietary recalls of infants' and toddlers' food and beverage intakes. Mothers or primary caregivers reported food intakes. A total of 3,022 infants and toddlers were included in this study. Ages were from four to 24 months. Beverages were categorized into six groups: total milks, $100 \%$ juice, fruit drinks, carbonated beverages, water, and "other" drinks. The carbonated group included all carbonated drinks such as carbonated mineral waters, and "diet" and "regular" products that may or may not contain sugar and caffeine. The "other" drink group included tea, cocoa, and other dry milk mixtures, and electrolyte replacement beverages for infants.

The Skinner et al (2004) study results revealed that beverages provided $84 \%$ of total energy (kcal) at four to six months, $43 \%$ at 12 to 14 months, and $36 \%$ at 19 to 24 months. Five percent of children from four to 14 months of age drank carbonated 
beverages. The percentage increased to over $11 \%$ for children from 15 to 24 months of age. Types of beverages consumed by these children included colas, fruit-flavored carbonated drinks, and carbonated mineral waters. These high-calorie, non-nutrient dense beverages are taking the place of low-calorie, nutrient-dense beverages. Even children at this young age are drinking these beverages which may be related to childhood overweight. These results emphasize why identifying factors that contribute to overweight and interventions to stop childhood overweight and obesity must start at a young age.

\section{High-Fructose Corn Syrup}

One component of soft drinks that may help to explain the relationship between soft drink consumption and overweight is high-fructose corn syrup (HFCS).

High-fructose corn syrup is a sweetener used in many processed foods. It is derived from cornstarch and is usually composed of 55\% fructose and $45 \%$ sucrose. Recently, there has been a rise in HFCS-containing food products such as soft drinks, baked goods, jelly, and ketchup. Commercially, the use of HFCS began to increase in the 1970s (Elliott et al, 2002). The per capita use of added fructose increased by $26 \%$, from $64 \mathrm{~g} /$ day in 1970 to $81 \mathrm{~g} /$ day in 1997 . Two $12 \mathrm{oz}$ regular soft drinks can provide $>10 \%$ of the energy requirement for an average woman.

Fructose is metabolized in the body differently than glucose. Glucose causes the pancreas to release insulin, fat cells to release leptin, and prevents the stomach from releasing ghrelin. Insulin drives sugar from the bloodstream into cells. Leptin is a hormone that makes you feel full, and ghrelin is a hormone that makes you feel hungry. 
Fructose does not release leptin or suppress the release of ghrelin. In other words, fructose may work to increase hunger and cause you to eat more.

\section{Television Viewing}

In 2001, the American Academy of Pediatrics (AAP, 2001) published a statement on children, adolescents, and television. This statement included possible negative health effects of television viewing on children and adolescents as well as a list of recommendations. Some of the possible negative health effects of television viewing stated were violent or aggressive behavior, obesity, poor body image, and decreased school performance. A few of the recommendations made by the AAP include limiting children's total entertainment media time to 1 to 2 hours a day, removing television sets from children's bedrooms, and increasing and encouraging alternate entertainment for children such as athletics, hobbies, and reading.

Ludwig et al (2001) looked at the relationship between television viewing and childhood obesity. Children were 11- to 12-year olds. Their results showed no significant relationship between television viewing and childhood obesity.

Crespo et al (2001) focused on finding a relationship between television watching and other sedentary behavior, energy intake, and obesity. The researchers used NHANES III (1988-1994). Data were collected on 4,069 children 8- to 16-years-old. To report hours of television watched, interviewers asked about television watched the previous day. Body composition was determined by using BMI. One diet technician used 24-hour dietary recalls to get information on food intake. The information from these recalls was entered into a food database that was linked to the US Department of Agriculture's (USDA) Survey Nutrition Database to obtain total energy intake. 
Results from this research revealed that approximately half of US children age 8to 16 -years watched more than two hours of television a day. Of the 4,069 children interviewed in NHANES III, $12.4 \%$ were obese. The highest incidence of obesity was in the 8 - to 10 -year-old age group for boys. When considering physical activity, $56.7 \%$ of US children engage in physical activity 5 or more days a week, this includes activity in school. The prevalence of obesity increased as hours of television watching increased. In addition, total energy intake was positively related with hours of television watched. Significant findings were that a higher incidence of obesity was related to more hours of television watching in girls. It is also important to study television watching in younger children and their risk of overweight and obesity.

Andersen et al (1998) assessed participation in vigorous activity and television watching and their relationship to body weight and fatness in US children. Data was for children aged 8 through 16 years and were part of NHANES III. Results showed that $20 \%$ of US children participated in 2 or fewer bouts of vigorous activity per week. This rate was higher for girls than for boys. Also, boys and girls who watched $\geq 4$ hours of television per day had greater body fat and a greater BMI $(\mathrm{P}<0.001)$.

The relationship between low-income preschool children's television viewing and risk of overweight was investigated by Dennison et al (2002). To collect data, parents with children 1- to 5-years old, participating in WIC at one of the 49 agencies in New York State in 1999 and/or 2000 were surveyed. Survey's were self-administered, although, assistance was available. Child weight and height or length were taken from the WIC chart. Television viewing was reported in hours per day "usually watched." Presence of a television in the child's room was also reported. Two thousand seven 
hundred sixty-one parents completed surveys. CDC cut points classified $37.2 \%$ of children had a BMI greater than the $85^{\text {th }}$ percentile. Almost $40 \%$ of parents reported that their children had a television set in their bedroom. Children with a television set in his/her bedroom spent more hours a week watching television than did those children without a television set in their bedroom. In addition, there was a higher prevalence $(\mathrm{P}<0.001)$ of overweight children among children with a television in their bedroom compared with those without. Overall, the researchers found that the amount of time spent watching television or videos was positively related to the prevalence of child overweight.

The relationship between television viewing and BMI has also been researched in Great Britain. Research performed by Viner and Cole (2005) examined the relationship between duration, timing, and type of television viewing at the age of five on BMI in adult life. The 1970 British Cohort Study was used in this research. It is a multidisciplinary longitudinal study that uses all those living in Great Britain (England, Scotland, and Wales) who were born in the week of April 5-11, 1970. These subjects were followed up at $5(\mathrm{n}=13,135), 10(\mathrm{n}=14,875)$ and $30(\mathrm{n}=11,261)$ years. When subjects were five years old, mothers provided data on hours of television watched per day during the week and weekends, time of viewing, and type of program watched. When subjects were 10 years old, mothers rated their child's television viewing as a frequency, "Rarely or never," "Sometimes," or "Often." At five years of age, height was measured, and at 10 years of age, height and weight were measured. BMI z-scores were calculated from the UK 1990 growth reference for 10 year-olds, and obesity was defined as a BMI greater than or equal to the $95^{\text {th }}$ percentile. When subjects were 30 years old, 
they self-reported height and weight. Subjects who were pregnant at the time of the interview reported pre-pregnancy weight. Adult BMI-scores were also calculated. Adult obesity was defined as a BMI greater than or equal to $30 \mathrm{~kg} / \mathrm{m}^{2}$.

Results of the Viner and Cole (2005) study revealed that obesity was found in $4.3 \%$ of subjects at 10 years, and $11.4 \%$ of subjects at 30 years. The only significant finding was that at 10 years, mean daily hours of television viewing on weekends predicted higher BMI z-scores at 30 years $(\mathrm{P}=0.01)$. The $\mathrm{z}$-score for an item indicates how far and in what direction, that item deviates from its distribution's mean, expressed in units of its distribution's standard deviation. These results suggest that only weekend television viewing affects adult BMI.

\section{Statement of the Problem}

The prevalence of overweight children in the US has significantly increased between 1983 and 1995 and continues to increase. Prevention of childhood overweight can help prevent the prevalence of chronic diseases later in life. Some factors identified that are concurrently rising with the increase of childhood overweight include soft drink consumption and television viewing. To our knowledge no one has examined video viewing and video game playing in relation to child BMI.

Since overweight is continuing to rise in children, the purpose of this study was to collect information on factors that may have an influence on weight status in children. The specific aims were:

1. To examine the prevalence of overweight in a group of children aged 2-6 years in McDowell and Mercer counties in West Virginia.

2. To examine the average daily soft drink consumption in this group. 
3. To determine the average number of hours of television/video viewing and video game playing in this group.

4. To determine if a relationship exists between mother's BMI and child BMI

\section{Methods}

\section{Research Design}

This study employed a quantitative, cross-sectional design (Brown et. al., 1999). The design is cross-sectional because children of different ages were studied at one point in time. The subject variables include male and female children of preschool age (two to six years-old) that, at the time of data collection, resided in McDowell or Mercer counties in West Virginia. Activities of preschool-aged children are determined by caregivers. Studying this age group allowed us to examine factors that parents could control in order to prevent childhood overweight. The independent variables are daily soft drink intake and hours of daily television/video viewing and video game playing and the dependent variable is child weight status determined by BMI percentile. There are two control or moderator variables in this study. They are familial factors and environmental factors. Some familial factors include the patents BMI, number of adults in the home, age of parent(s), and number of siblings. Environmental factors include the mother's and/or father's occupation and education. These variables may affect soft drink intake, hours of television viewing and/or body mass index. See Figure 3 in Appendix $\mathrm{C}$ for an illustration of the hypothesized relations between these variables.

\section{Participants}

Two-hundred and three participants were in the study. The sample was nonrandomly selected. The ages of the participants are from two to six years old. Both 
males and females were in the study. Children could be of any weight, height, physical health status, or ethnicity to participate in the study.

Background information was collected by using a background questionnaire (see Appendix D). The background information was used to help determine the effects of control or moderator variables on the independent and/or dependent variables. The background questionnaire was also used to find information on the participants' gender, age, number of siblings, number of adults in the household, and any known medical conditions. Parents self-reported background information.

\section{Sample Selection}

The sampling strategy used was non-random, non-probability, haphazard sampling. This strategy was used to help reach the number of participants needed. It would be difficult to attain the number of participants desired if random sampling was used. Nonrandom, haphazard sampling is a time and money efficient way to obtain a sample. The sample was in McDowell and Mercer counties in West Virginia.

Preschoolers and parents participating in the WVU Extension Services Family Nutrition Program (FNP) Head Start Program in McDowell and Mercer counties were invited to participate. Also, signs explaining the study were posted in grocery stores, parks, and other areas frequented by parents of preschoolers. The signs had a telephone number for the parents to call if they were interested. Those parents who chose to participate were given a $\$ 20.00$ gift certificate to a local discount store (see Appendix E).

\section{Procedures}

Investigators met with interested parents to further explain the study, to answer questions, and to get informed parental consent before their children were enrolled. The 
WVU Institutional Review Board approved the study for the Protection of Human Subjects.

The data were collected over a one year period. Participants in the study were weighed on an electronic scale and their height was measured with a portable stadiometer. Children were in light, indoor clothing and without shoes when the measurements were done. This information was collected on site at schools, health fairs, etc. in McDowell and Mercer counties. Extension personnel and hourly workers from McDowell and Mercer counties collected data. The investigators trained these individuals prior to data collection. In order to determine subject soft drink intake, a multiple pass 24-hour recall was given to the primary caregiver. To assure anonymity and confidentiality, each participant was assigned a number. The list of participants with their assigned number has been destroyed. The data were recorded in booklets that contained only the participants' identification number, gender, and ethnicity.

\section{Instrumentation}

BMI was determined by using the collected weight and height data. To calculate BMI, the formula weight $\mathrm{kg} /[\text { height }(\mathrm{m})]^{2}$ was used. From this, BMI percentile was estimated using growth charts (CDC, Atlanta, GA, 2000). See Appendix F for an anthropometric measures record sheet and Appendix G for BMI percentile charts. Once BMI percentile was calculated, the children were placed into one of two groups based on the following definitions. Normal weight was defined as a BMI $<85^{\text {th }}$ percentile.

Overweight was defined as $\mathrm{BMI} \geq 85^{\text {th }}$ percentile. Therefore, in this study, there were two groups when considering weight status. 
The parents' self-reported weight and height were used to calculate BMI in the same way that it was performed for the children. BMI $\geq 25$ was defined as overweight. A BMI $\geq 30$ was defined as obese.

To collect data on soft drink intake, the multiple pass 24-hour recall was used. The recall was given in an interview format. The first pass was used to ask respondents to recall the foods that children consumed the previous day. This pass was a quick list of food items that includes the time and occasion the food was eaten. The next pass gave the interviewer a chance to ask a series of questions about each food reported. This pass had questions about the amounts of the foods served and eaten and any added ingredients. During the last pass, the responses were reviewed and additional details were taken from the respondents. This pass had questions about the typical eating habits of the child. The multiple passes help to ensure reliability with the recall. This type of dietary intake collection has been used for many other similar studies (Serdula et al., 2001). See appendix $\mathrm{H}$ for sample intake forms. Soft drink intake and hours of television viewing were compared between BMI groups using a t-test. $\mathrm{P} \geq 0.05$ indicated significance. Any relationship between mother's BMI and child's BMI was analyzed by linear regression. The statistical analysis was performed using Sigmastat (Version 3.1, WVU).

\section{$\underline{\text { Results }}$}

A total of 201 subjects were included in the analyses. There were 93 male and 108 females subjects. The mean age was $52 \pm 10.2$ months with a range of 26 to 71.8 months. African-Americans made up $11.6 \%$ of subjects. Mean weight of subjects was $40.3 \pm 9.54 \mathrm{~kg}$. Mean height of subjects was $41.15 \pm 3.17$ inches. Mean BMI of subjects was $16.58 \pm 2.52 \mathrm{~kg} / \mathrm{m}^{2}$ with a range from 12.2 to 34 . Of the 201 subjects, $33.8 \%$ were 
overweight (BMI above the $85^{\text {th }}$ percentile) and $66.2 \%$ were normal weight. For mothers, $30.5 \%$ were obese $(\mathrm{BMI} \geq 30$ ) and $31 \%$ were overweight $(\mathrm{BMI} \geq 25)$.

The only significant finding was a positive correlation between mom's BMI and child BMI $(\mathrm{P}<0.001 ; \mathrm{r}=0.336)$. One-hundred and eighty mom's BMI values were able to be calculated.

One-hundred and seventy-seven food recalls were completed. Of the 177 subjects with dietary intake recorded, $74.6 \%$ were nonconsumers of soft drinks (those consuming no soft drinks during the day of dietary recall), $22.6 \%$ consumed one soft drink ( $8 \mathrm{fl} \mathrm{oz})$ during the day of dietary recall, and only $2.8 \%$ consumed 2 soft drinks during the day of dietary recall. See Chart 1.

Chart 1. Subject soft drink consumption

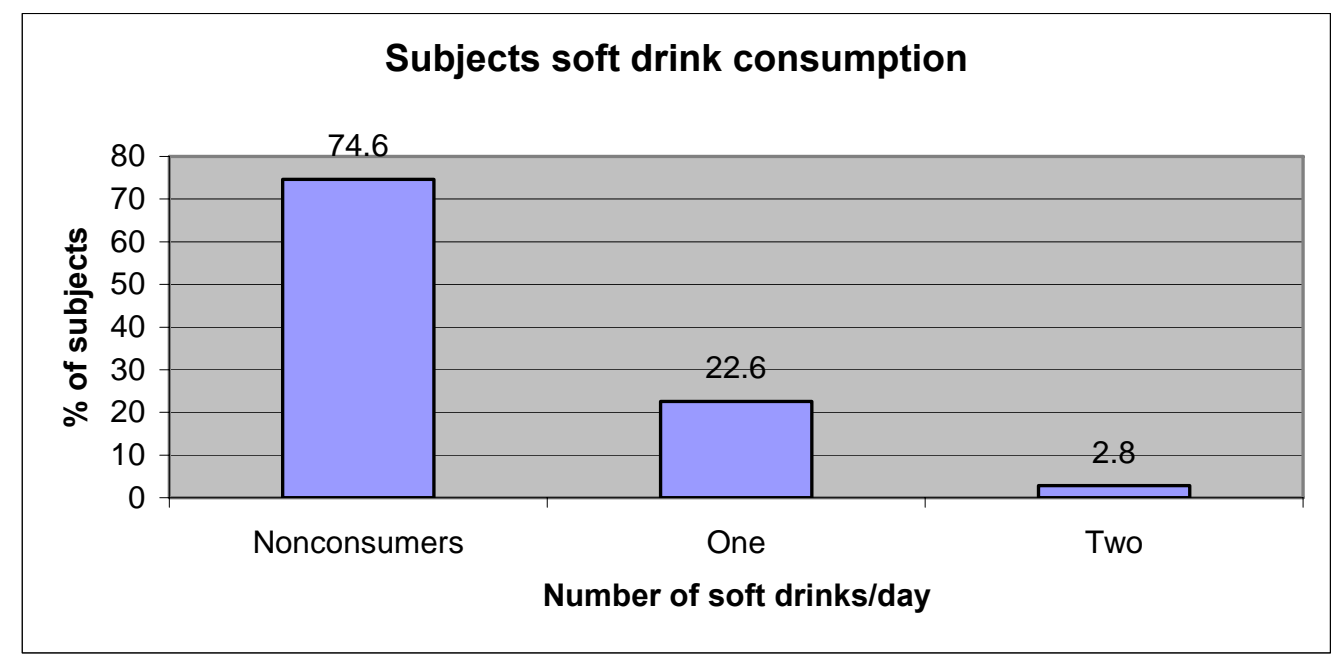

Using t-test, there was no significant difference $(\mathrm{P}>0.050)$ in soft drink intake between normal weight and overweight subjects. The mean number of $8 \mathrm{fl} \mathrm{oz} \mathrm{soft} \mathrm{drink}$ consumed per day by normal weight subjects was $0.317 \pm 0.550$ while the for overweight subjects, the mean number of soft drinks consumed was $0.214 \pm 0.414$. 
There was no significant age differences $(\mathrm{P}>0.050)$ in age between normal weight and overweight subjects. The average age of the subjects was $52 \pm 10.2$ months (4 years and 5 months).

Daily hours of television viewing were not significantly different $(\mathrm{P}>0.05)$ between normal weight and overweight subjects when a t-test was used. The mean number of hours of television viewed by normal weight subjects was $2.59 \pm 1.5$ and for overweight children, the mean hours of television viewed daily was $2.37 \pm 1.42$.

When television and video hours were combined, there were also no significant differences $(\mathrm{P}>0.050)$ between normal and overweight subjects.

There were no significant differences in soft drink intake, television/video viewing, and video game viewing between male and female participants. $\mathrm{P}>0.05$.

\section{$\underline{\text { Discussion }}$}

We studied factors that may influence child's BMI. When considering soft drinks, results were in agreement with Harnack et al (1999) that most children (age 2-to 5-year olds) were nonconsumers of soft drinks. However, they found that $49.5 \%$ of preschool age children were nonconsumers of soft drinks, which is less than the $74.6 \%$ found in this study. The results may have differed because Harnack, et al were focusing on preschool age children throughout the United States.

These results contradict the results found by Nielsen and Popkin (2004); however, they looked at 2-18 year-olds and we looked at 2-6 year-olds. Results from their research revealed that between 1977 and 2001, Americans increased the proportion of total energy obtained from soft drinks from $2.8 \%$ to $7.0 \%$. In the 2 - to 18 -year-old age group, soft 
drink consumption increased from $3.0 \%$ to $6.9 \%$ of total energy. Their results may have more accurately reflected the soft drink intake of older subjects.

It would have been interesting to investigate the presences of differences in all HFCS-sweetened beverages and/or food, rather than just examining soft drinks. As discussed in the review of literature, high intake of HFCS is associated with an increase the body's lipid production and an increase in food consumption.

When considering television and video viewing, results from this study agree with those found by Ludwig, et al (2001). That showed no significant relationship between television viewing and childhood weight. Although, they were focusing on childhood obesity $\left(\geq 95^{\text {th }}\right.$ percentile) while this study centered on childhood overweight $\left(\geq 85^{\text {th }}\right.$ percentile). Conversely, Crespo et al. (2001) results revealed that the prevalence of obesity increased as hours of television watching increased. Crespo et al. results also showed that a higher incidence of obesity was related to more hours of television watching in girls. We did not have similar results. Both were looking at an older age group than we did and both studies had a larger sample sizes than this study. However, neither of these studies reported analyzing video games as this study did.

Unique to this study was the fact that hours of video games played were included with hours of television and videos viewed. No other study has studied a relationship between child TV/video viewing along with video game playing and overweight. However, this study showed no effect of video or video game playing on BMI. This study also focused on a smaller age group than some others.

In this study the group was limited to 2- to 6-year-olds while other studies used age broad age groups up to 2- to 18-year-olds. Activities of preschool-aged children are 
determined by caregivers. Studying this age group allowed us to examine factors that parents could control in order to prevent childhood overweight. This study also focused on a rural state. Rural areas are sparsely settled places away from the influence of large cities and towns. These areas are also limited in many services, especially public services.

The only significant finding was that mothers' BMI was positively related to child BMI. This is in agreement with the findings of Whitaker et al (1997) where parental obesity more than doubled the risk of adult obesity among both obese and non-obese children under 10 years of age. Our study only used maternal BMI because many heights and/or weights were not available for fathers.

A positive relationship between mom's BMI and child BMI could suggest either a genetic or environmental relationship to overweight and obesity. However, since there were no significant differences in either of the environmental factors in this study, soft drink intake or television and video viewing, between normal weight and overweight subject, these results lean toward a genetic relationship to overweight and obesity.

Factors that could have biased the results in this study include self-reported data and parental perspective. There are always limitations to self-reported data. In a 24-hour food recall, there are many chances for error. For some, it may be difficult to remember what their child or children ate the previous day, especially specific amounts of the food eaten. Also, in the population studied, many children attended Head Start or other programs where parents do not see what their children eat everyday. Parents may also be reluctant to report their actual weight and height. As for parental perspective, caregivers may not provide information that may be perceived as negative about their children. 
Using this research as part of a prospective study could be beneficial in examining the most vulnerable time for the onset of overweight and obesity. It could also be useful to help describe childhood habits that may be related to overweight and obesity later in life.

\section{Conclusion}

Our study on rural WV preschool-aged (2- to 6-year-olds) children showed there were no significant differences between overweight and normal weight children when examining daily soft drink intake, television/video viewing, television/video viewing and video game playing, or age. However, the results show a positive relationship between a mother's BMI and her child's BMI. Factors previously believed to contribute to the increase in childhood overweight were not significantly related to overweight in these rural WV preschool-aged children. These results indicate a need for further studies on factors relating to overweight in rural WV preschool-aged children. Future studies are already being planned to increase the knowledge on factors relating to overweight in rural WV preschool-aged children. 


\section{References}

American Academy of Pediatrics, Committee on Public Education. Children, adolescents, and television. Pediatrics. 2001; 107: 423-26.

American Diabetes Association. Diabetes Statistics. Available at: http://www. diabetes.org/diabetes-statistics.jsp. Accessed February 27, 2006.

Andersen RE, Crespo CJ, Barlett SJ, Cheskin LJ, Pratt M. Relationship of physical activity and television watching with body weight and level of fatness among children. JAMA. 1998; 279: 938-942.

Berenson GS. Obesity- a critical issue in preventive cardiology: The Bogalusa Heart Study. Prev Cardiol. 2005; 8: 234-41.

Brown KW, Cozby PC, Kee DW, Worden PE. Research Methods in Human Development. 2nd ed. Calif.: Mayfield Publishing Company; 1999.

Crespo CJ, Smit E, Troiano RP, Bartlett SJ, Macera CA, Anderson RE. Television watching, energy intake, and obesity in US children. Results from the Third National Health and Nutrition Examination Survey, 1988-1994. Arch Pediatr Adolesc Med. 2001; 155: 360-365.

Dennison BA, Erb TA, Jenkins PL. Television viewing and television in bedroom associated with overweight risk among low-income preschool children. Pediatrics. 2002; 109: 1028-35.

Elliott SS, Keim NL, Stern JS, Teff K, Havel PJ. Fructose, weight gain, and the insulin resistance syndrome. Am J Clin Nutr. 2002; 76: 911-22.

Freedman DS, Dietz WH, Srinivasan SR, Berenson GS. The relation of overweight to cardiovascular risk factors among children and adolescents: the Bogalusa heart study. Pediatrics. 1999; 103: 1178-1182. Available at: http://www.pediatrics. org/cgi/content/full/103/6/1175. Accessed November 20, 2004.

Harnack L, Stang J, Story M. Soft drink consumption among US children and adolescents: Nutritional consequences. J Am Diet Assoc. 1999; 99: 436-441.

Kavey REW, Daniels SR, Lauer RM, Atkins DL, Hayman LL, Taubert K. American Heart Association guidelines for primary prevention of atherosclerotic cardiovascular disease beginning in childhood. Circulation. 2003; 107: 15621566.

Ludwig DS, Peterson KE, Gortmaker SL. Relation between consumption of sugarsweetened drinks and childhood obesity: a prospective, observational analysis. The Lancet. 2001; 357: 505-508. 
Magarey AM, Daniels LA, Boulton TJ, Cockington, RA. Predicting obesity in early adulthood from childhood and parental obesity. Int J Obes Relat Metab Disord. 2003; 27: 505-13.

Mei Z, Scanlon KS, Grummer-Strawn LM, Freedman DS, Yip R, Trowbridge FL. Increasing prevalence of overweight among US low-income preschool children: The Centers for Disease Control and Prevention Pediatric Nutrition Surveillance, 1983 to 1995. Pediatrics. 1998; 101: e12-17. Available at http://www.pediatrics.org/cgi/content/ full/101/1/e12. Accessed September 19, 2005.

Nielsen SJ, Popkin BM. Changes in beverage intake between 1977 and 2001. Am J Prev Med. 2004; 27: 205-210.

Northstone K, Rogers I, Emmett P, ALSPAC Study Team. Drinks consumed by 18month-old children: are current recommendations being followed? Eur J Clin Nutr. 2002; 56: 236-244.

Ogden CL, Troiano RP, Briefel RR, Kuczmarski RJ, Flegal KM, Johnson CL. Prevalence of overweight among preschool children in the United States, 1971 through 1994. Pediatrics. 1997; 99: e1-7. Available at http://www.pediatrics.org/cgi/content/full /99/4/e1. Accessed September 19, 2005.

Ogden CL, Flegal KM, Carrol MD, Johnson CL. Prevalence and trends in overweight among US children and adolescents, 1999-2000. JAMA. 2002; 288: 1728-1732.

Serdula MK, Alexander MP, Scanlon KS, Bowman BA. What are preschool children eating? A review of dietary assessment. Annu Rev Nutr. 2001; 21:475-98.

Skinner JD, Ziegler P, Ponza M. Transitions in infants' and toddlers' beverage patterns. $J$ Am Diet Assoc. 2004; 104:S45-S50.

St-Onge MP, Keller KL, Heymsfield SB. Changes in childhood food consumption patterns: a cause for concern in light of increasing body weights. Am J Clin Nutr. 2003; 78: 1068-73.

Viner RM, Cole TJ. Television viewing in early childhood predicts adult body mass Index. J Pediatr. 2005; 147: 429-35.

West Virginia Demographics. National Center for Children in Poverty. Columbia University. Available at: http://www.nccp.org/state_detail_demographic _wv.html\#definitions. Accessed December 9, 2004. 
West Virginia Department of Health and Human Resources, Bureau for Public Health, Office of Epidemiology and Health Promotion. West Virginia County Health Profiles, 2004.

Whitaker RC, Wright JA, Pepe MS, Seidel KD, Dietz WH. Predicting obesity in young adulthood from childhood and parental obesity. N Engl J Med. 1997; 337: 86973. 
Appendix A

Figure 1

Figure 2

Pirexalance of Qbesity by Caunty

West Virginia BRFSS, 1990-1994 and 1995-1999

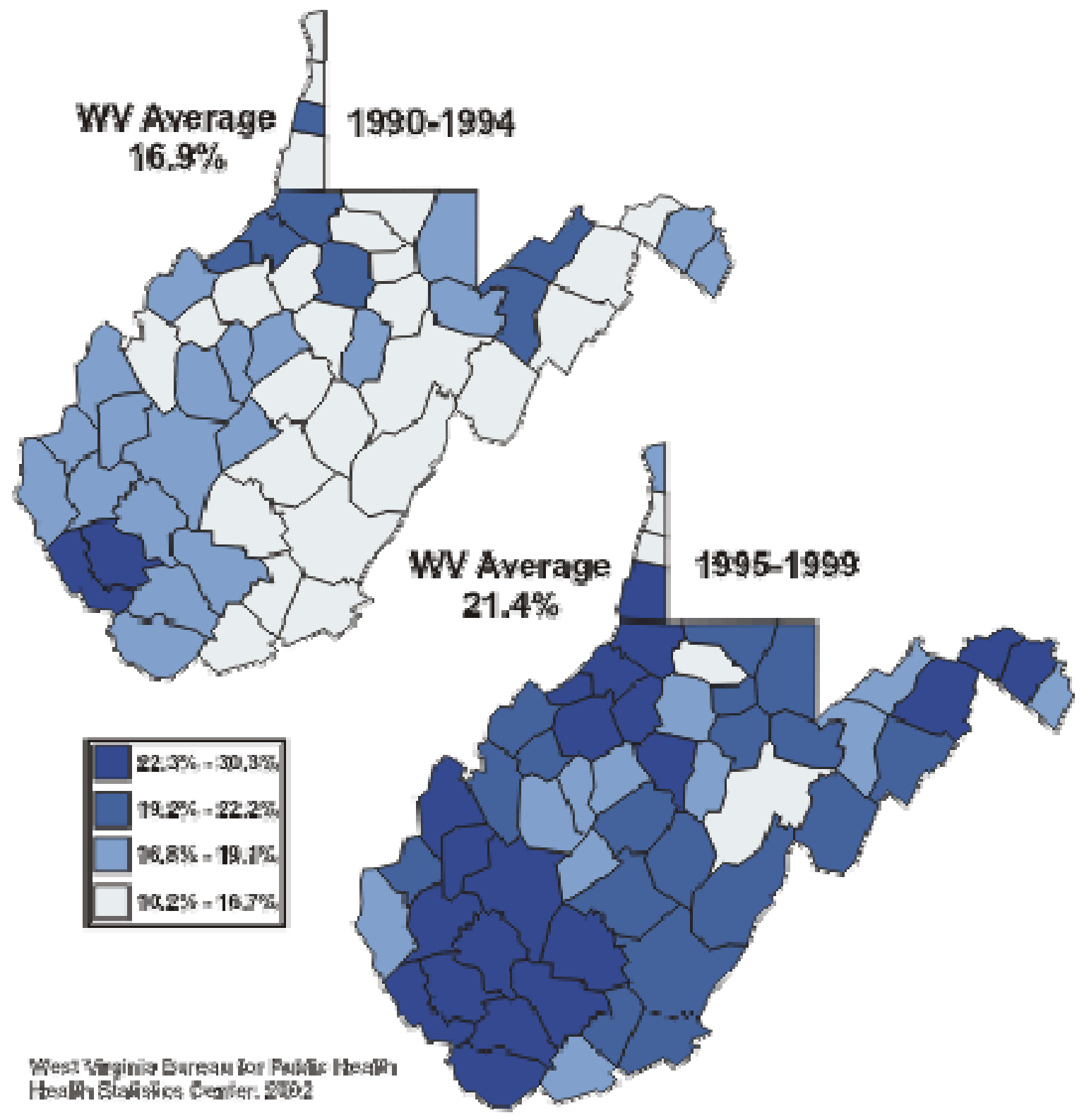


Appendix B

Figure 2

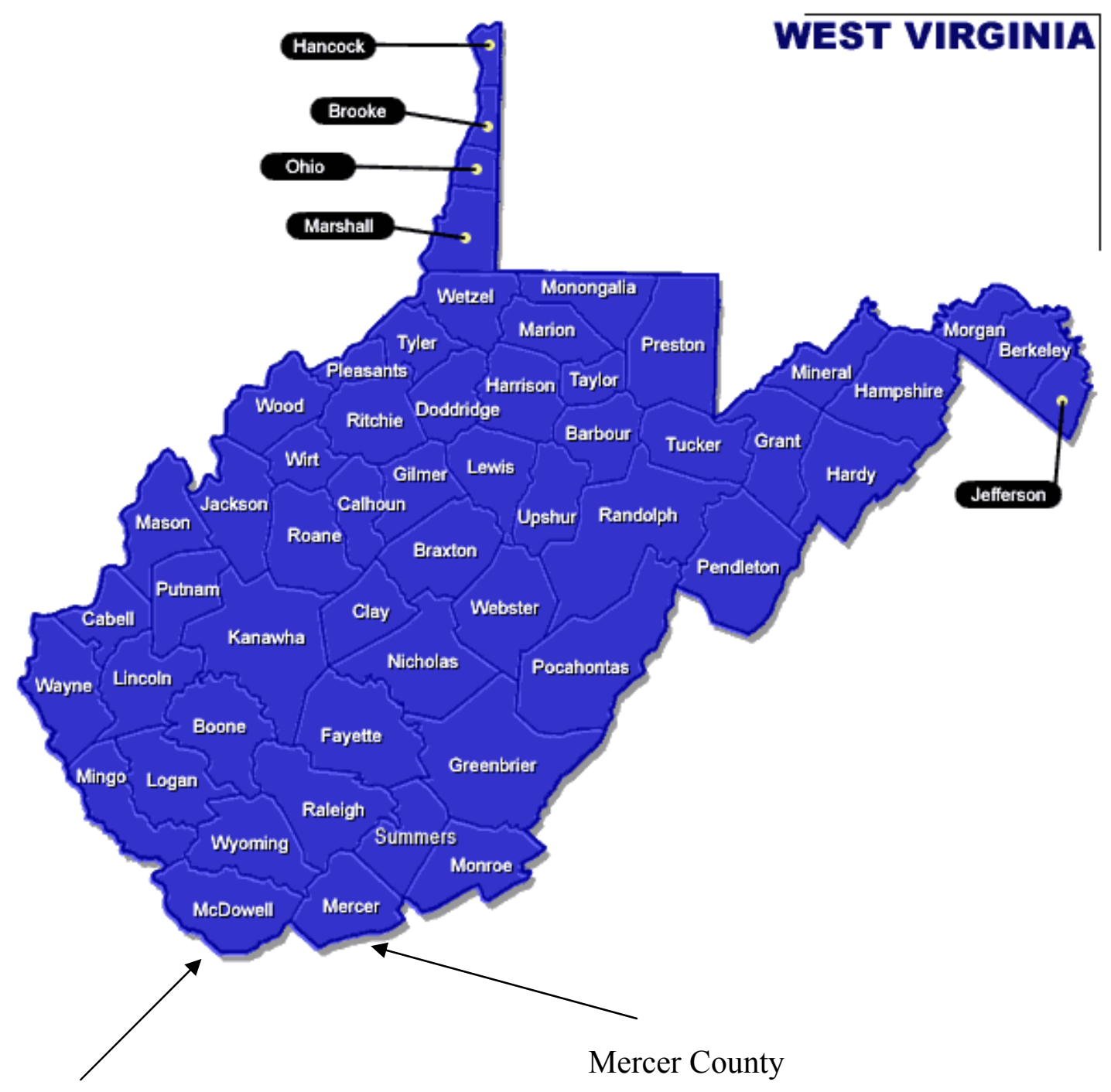

McDowell County 
Appendix C

Figure 3

Conceptualization of Variables of Interest and their Hypothesized Relations

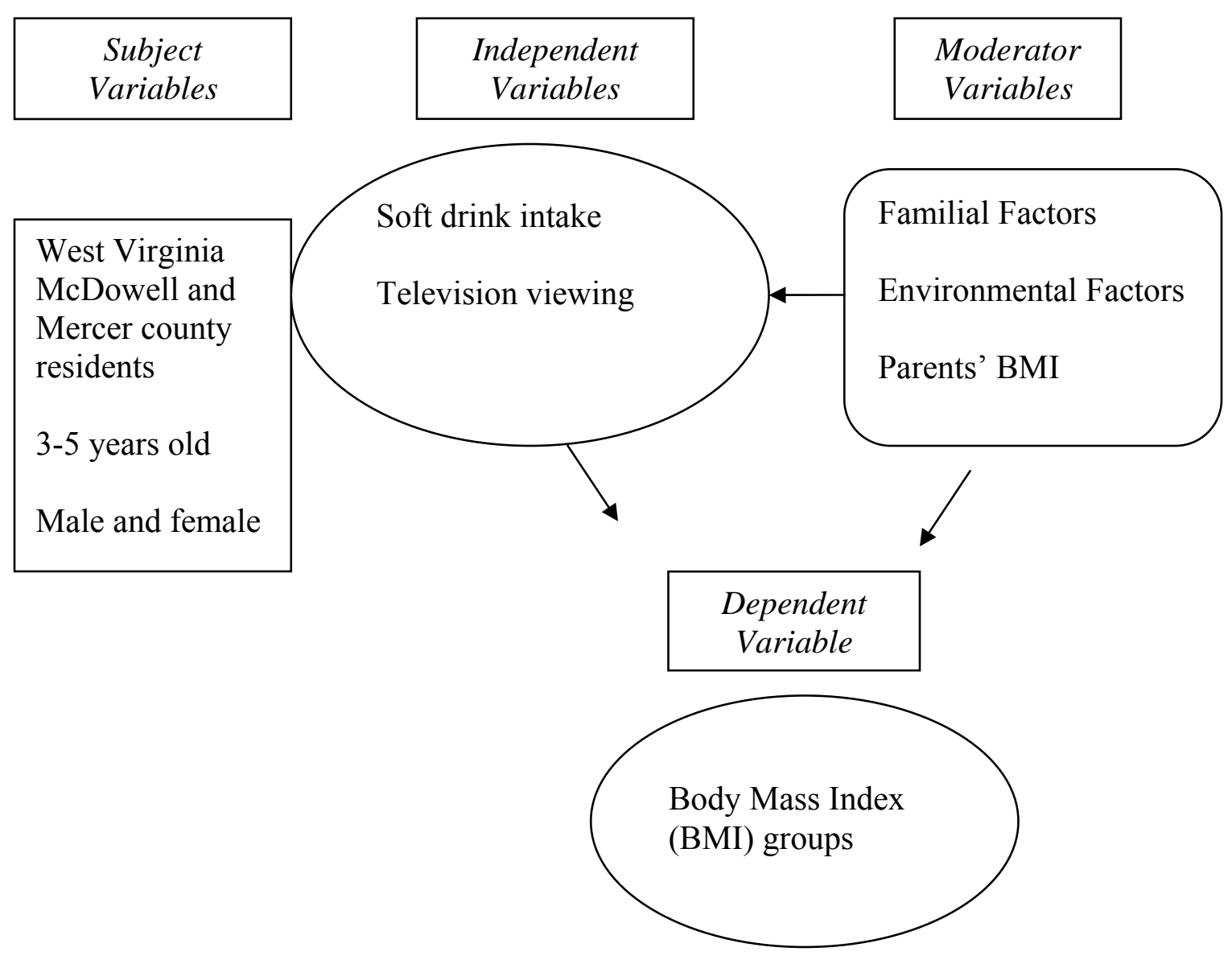


Appendix D

\section{Parent Information Form}

Name

Mother's Age

Less than 20 years

20 to 29 years

30 to 39 years

40 to 49 years

50 years or greater

Mother's height

Mother's weight

Number of adults in home

Who is primarily responsible for food purchases?

Food preparation?

\section{Mother's education level}

Less then 12 years

High School diploma or equivalent

Some college courses

College degree

Graduate degree

\section{Mother's Occupation}

Number of hours worked per week
Father's Age

Less than 20 years

20 to 29 years

30 to 39 years

40 to 49 years

50 years or greater

Father's height

Father's weight

How many hours per day does your child spend watching television or videos? Playing video or computer games?

Father's education level

Less than 12 years

High School diploma or equivalent Some college courses

College degree

Graduate degree

\section{Father's Occupation}

Hours worked per week

Does he/she have a television in his/her room? 
Appendix E

\title{
ATTENTION PARENTS OF PRESCHOOLERS!
}

\author{
The West Virginia University \\ Division of Family \& Consumer Sciences \\ And \\ Extension Service
}

Are conducting a research study to determine factors that influence dietary intake and growth in preschool aged children

If your child is between the ages of three and five years, he or she is eligible to participate in this study

Learn more about your child's growth and diet

Participate in a research project that will help determine why some children are underweight and others are overweight

Time required: About 1 hour

Procedures: Your child will be weighed and measured and you will be asked to provide information about his/ her food intake and to answer a series of questions about your thoughts and practices regarding food

Information: $\quad$ Cindy Fitch, WV - 304- 293- 3402, extension 1768 Lisa Mitchell, Extension Agent - 304- 425- 3079

Thank you gift: $\quad \$ 20.00$ gift certificate 
Appendix E

\section{Dear Parent,}

Thank you for allowing your child to participate in this research study designed to determine the factors that influence the growth of preschool aged children in West Virginia. As you are aware, children who are too thin or who are overweight may experience health problems in the future. We expect this study to identify some of the reasons that children may be over- or underweight, but to do so we need to get a little information from you. Please take a few minutes to fill out the following surveys. We estimate that it will take you about 1 hour to fill out the surveys. Your answers will be kept confidential. If you have any questions or concerns, please call me at 304-293-3402, extension 1768.

Thank you,

Cindy Fitch, Ph.D., RD

Assistant Professor, Human Nutrition and Foods

Lisa R. Mitchell, MS

County Extension Agent, McDowell County 
Appendix F

Record sheet for anthropometric measures

Date of Birth

Age (months)

\section{Growth Parameters}

Child's weight

Child's height

WHP*

*

HAP* $^{*}$
WAP* $^{*}$
WHZ* $^{*}$

HAZ*

WAZ*

BMI

BMI\%

Other comments:

\begin{abstract}
$*$
$\mathrm{HAP}=$ Height for age percentile

$\mathrm{HAZ}=$ Height for age $\mathrm{z}$-score

$\mathrm{WAP}=$ Weight for age percentile

$\mathrm{WAZ}=$ Weight for age $\mathrm{z}$-score

$\mathrm{WHP}=$ Weight for height percentile

$\mathrm{WHZ}=$ Weight for height $\mathrm{z}$-score
\end{abstract}




\section{Appendix G}

2 te 20 years Bross

Body mass index-fov:age pereentiless

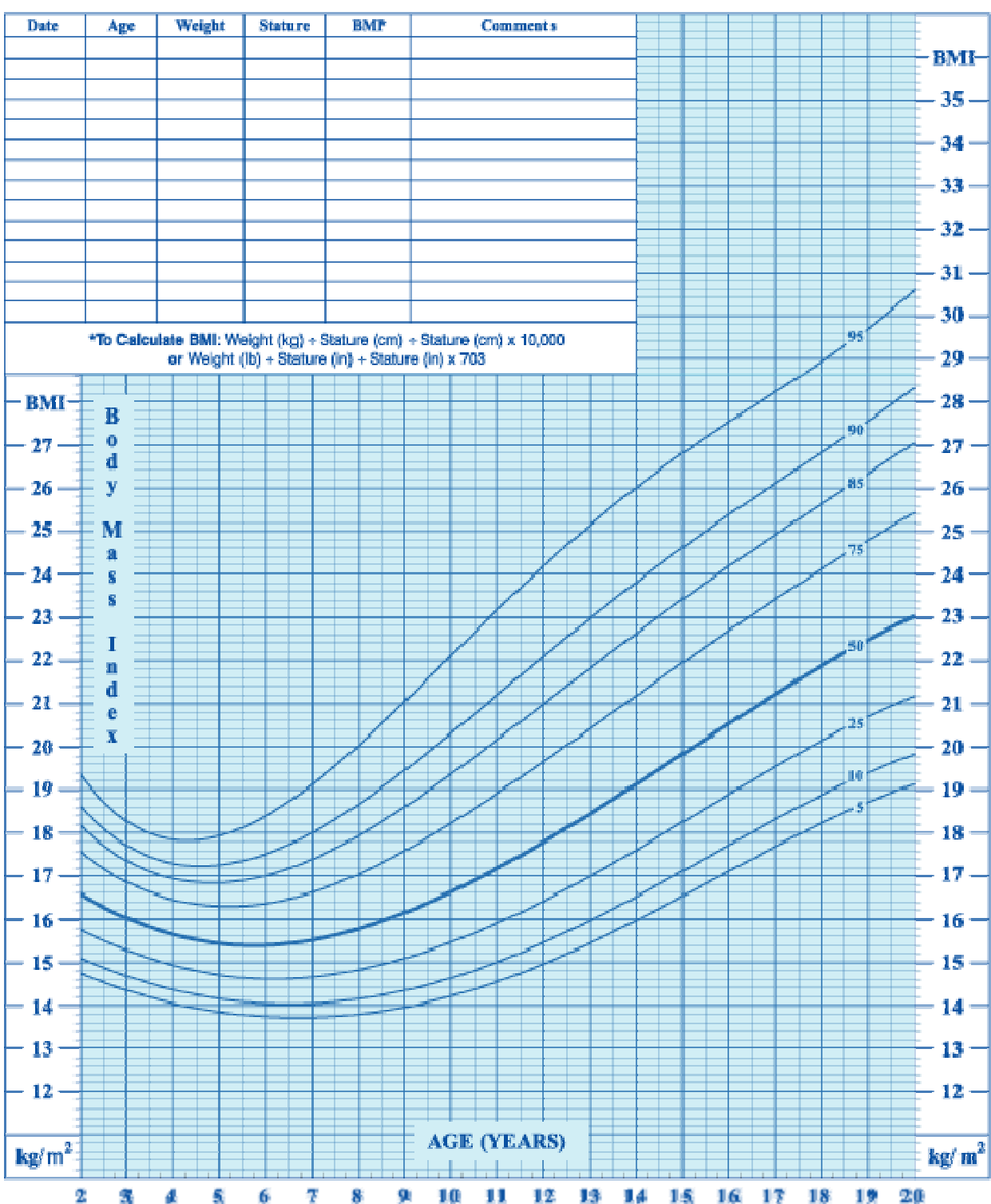

NAWE:

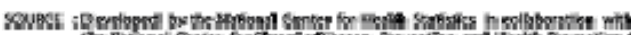

About Pediatrics 
Appendix H Individual Intake Forms
ID Number

\begin{tabular}{|l|r|r|}
\hline \multicolumn{1}{|c|}{$\begin{array}{c}\text { Column1 } \\
\text { Quick List of Food Items }\end{array}$} & $\begin{array}{r}\text { Column 2 } \\
\text { Time }\end{array}$ & $\begin{array}{c}\text { Column 3 } \\
\text { Occasion }\end{array}$ \\
\hline A. & & am \\
pm
\end{tabular}


Appendix $\mathrm{H}$

ID Number

Page 2

\begin{tabular}{|c|c|c|}
\hline Food/Drink with Additions & $\begin{array}{c}\text { Column } 4 \\
\text { Description of Food/Drink } \\
\text { and Ingredient Amounts }\end{array}$ & $\begin{array}{c}\text { Column } 5 \\
\text { How much of this } \\
\text { (FOOD) did (NAME) } \\
\text { actually (eat/drink)? }\end{array}$ \\
\hline 1. & & \\
\hline 2. & & \\
\hline 3. & & \\
\hline 4. & & \\
\hline 5. & & \\
\hline 6. & & \\
\hline 7. & & \\
\hline 8. & & \\
\hline 9. & & \\
\hline 10. & & \\
\hline 11. & & \\
\hline 12. & & \\
\hline 13. & & \\
\hline 14. & & \\
\hline 15. & & \\
\hline 16. & & \\
\hline 17. & & \\
\hline 18. & & \\
\hline 19. & & \\
\hline
\end{tabular}


20.

12. Amount of food Usual Less More

13. Reason

15. Ounces of plain drinking water

16. Amount from home

17. Source of water outside of home

18. Special formula or diet?

19. Vitamin or minerals Daily Occasionally Not at all

20. Types of supplements (brand)

Interviewer Observations

1. Main respondent

2. Additional respondent

3. Any difficulty

4. Reason

5. Information for follow-up phone call 


\title{
MEREDYTHE A. BARRICK
}

\author{
3 Valencia Courts \\ Morgantown, WV 26505 \\ (304) 813-7022 \\ mnewlin@mix.wvu.edu
}

\section{EDUCATION}

West Virginia University, Morgantown, WV

Davis College of Agriculture, Forestry and Consumer Sciences

Master's of Sciences in Family and Consumer Sciences, May 2006

4.0/4.0 GPA

West Virginia University, Morgantown, WV

Davis College of Agriculture, Forestry and Consumer Sciences

Bachelor's of Sciences in Family and Consumer Sciences, May 2004

3.76/4.0 GPA

Potomac State College of West Virginia University, Keyser, WV

Associate of Arts in General Sciences, May 2002

3.65/4.0 GPA

FOOD AND NUTRITION RELATED WORK EXPERIENCE

August 2004-May 2005

Graduate Assistant

West Virginia University, Morgantown, WV

Assist nutrition professors with classes

Instruct classes

April 2000-August 2002,

Food Service Employee

May 12, 2003-August 2003

Keyser Dairy Queen, Keyser, WV

May 2004-August 2004

Preparation and service of food

Lead co-workers

\section{EXPERIENTIAL INTERNSHIP ROTATIONS COMPLETED}

June 6, 2005-June 10, 2005

Community Nutrition

Partners in Corporate Health,

Morgantown, WV

Deanna Pyles RD, LD 
June 20, 2005-June 22, 2005

June 27, 2005-July 1, 2005

July 11, 2005-July 22, 2005

July $26,27, \& 29,2005$

August 1, 2005-August 5, 2005

September 12, 2005-September 16, 2005

September 19, 2005-November 4, 2005

November 7, 2005-November15, 2005

November 16, 2005-November 17, 2005
Community Nutrition

WVU Extension Service,

Morgantown, WV

Dr. Guendoline Brown

Community Nutrition

Nutrition Services, WIC,

Morgantown, WV

Roberta Conner

Community/Clinical Nutrition

Center for Excellence in Disabilities

Morgantown, WV

Monica Andis RD, LD

Community Nutrition

Meals on Wheels,

Morgantown, WV

Betty Veach

Community Nutrition

WVU Extension Service, 4-H Day Camp,

Morgantown, WV

Randall Schoonover

Sports Nutrition

WVU Football team,

Morgantown, WV

Jason Pompili, Strength Coach

Foodservice

WVU Residential Services

Morgantown, WV

Nettie Puglisi

School Nutrition

Monongalia County Board of Education

Morgantown, WV

Laura Savio MS, RD, LD

Community Nutrition

WVU Extension Service

Morgantown, WV

Belinda Owens 
November 28, 2005-November 29, 2005

January 9, 2006-March 24, 2006

April 10, 2006-April 14, 2006
Community Nutrition

Fairmont State University

Fairmont, WV

Pamela Hamilton MS, RD, LD

Clinical Nutrition

Monongalia General Hospital

Morgantown, WV

Melinda Zook-Weaver RD, LD

Renal Nutrition

Morgantown Dialysis Center

Morgantown, WV

Sara Clark, MS, RD, LD

\section{HONORS AND AWARDS}

Graduated Summa Cum Laude from West Virginia University, May 2004

Mountaineer Scholar at West Virginia University

2003-2004 William A. Wayt Scholar at West Virginia University

Gelwick Scholar at Potomac State College of West Virginia University

Westvaco Scholar at Potomac State College of West Virginia University

Beta Sigma Phi Epsilon Scholar at Potomac State College of West Virginia University

Golden Key International Honor Society at West Virginia University

Phi Upsilon Omicron National Honor Society at West Virginia University

Sigma Phi Omega Honor Society at Potomac State College of West Virginia University

Who's Who Among Students in American Junior Colleges at Potomac State College of West Virginia University

Outstanding French Student at Potomac State College of West Virginia University

Dean's List of Distinguished Students Fall 2000, Spring 2001 at Potomac State College of West Virginia University

President's List Fall 2001, Spring 2002 at Potomac State College of West Virginia University

President's List Fall 2002, Spring 2003 at West Virginia University

\section{ACTIVITIES}

Participate in Relay for Life

Volunteer in Family Nutrition Program of West Virginia University Extension Service Volunteer at Church Spaghetti Dinners 
Prepare Dinner at Ronald McDonald House, Morgantown

Volunteer at Heartland Nursing Home in Keyser

27 Hours of Shadowing Dietitians

American Dietetic Association

West Virginia Dietetic Association

Student Dietetic Association at West Virginia University

2003-2004 Treasurer of Phi Upsilon Omicron at West Virginia University

Participate in Student Dietetic Association Activities

Co-chair Fundraising Committee in Student Dietetic Association

Foreign Language Club at Potomac State College of West Virginia University

Life Science Club at Potomac State College of West Virginia University

Prepare Meals for Energy Express, Keyser 